\title{
The Role of Smoking and Nicotine in the Transmission and Pathogenesis of COVID-19
}

\author{
Ali Ehsan Sifat, Saeideh Nozohouri, Heidi Villalba, Bhuvaneshwar Vaidya, \\ and Thomas J. Abbruscato \\ Department of Pharmaceutical Sciences, School of Pharmacy, Texas Tech University Health Sciences Center, Amarillo, Texas
}

Received June 16, 2020; accepted September 30, 2020

\begin{abstract}
Coronavirus disease 2019 (COVID-19), caused by the severe acute respiratory syndrome coronavirus 2 virus, is turning out to be one of the most devastating global pandemics in the history of humankind. There is a shortage of effective therapeutic strategies or preventative vaccines for this disease to date. A rigorous investigation is needed for identifying and developing more effective therapeutic strategies for COVID-19. Angiotensin-converting enzyme 2 (ACE2), a crucial factor in COVID-19 pathogenesis, has been identified as a potential target for COVID-19 treatment. Smoking and vaping are potential risk factors for COVID-19 that are also shown to upregulate ACE2 expression. In this review, we have discussed the pathobiology of COVID-19 in the lungs and brain and the role of ACE2 in the transmission and pathobiology of this disease. Furthermore, we
\end{abstract}

have shown possible interactions between nicotine/smoking and ACE2 in the lungs and brain, which could aggravate the transmission and pathobiology of COVID-19, resulting in a poor disease outcome.

\section{SIGNIFICANCE STATEMENT}

This review addresses the present global pandemic of coronavirus disease 2019 (COVID-19) with respect to its pathobiology in the lungs and brain. It focuses on the potential negative impact of tobacco and nicotine exposure on the outcomes of this disease by interaction with the angiotensin-converting enzyme 2 receptor. It adds to the time-sensitive and critically important growing knowledge about the risk factors, transmission, pathobiology, and prognosis of COVID-19.

\section{Introduction}

Coronavirus disease 2019 (COVID-19) has become the most significant health hazard in the world since the flu pandemic in 1918. It is the disease caused by the severe acute respiratory syndrome coronavirus 2 (SARS-CoV-2) virus. Approximately 27.5 million people worldwide have been infected with the virus, which has resulted in 894,983 deaths as of September 9, 2020 (https://www.who.int/emergencies/diseases/ novel-coronavirus-2019). The virus emerged from the city of Wuhan, Hubei Province, China, in December 2019 (Li et al., 2020b). Due to its significantly high contagiousness (Du et al., 2020; Li et al., 2020b; Riou and Althaus, 2020), the virus quickly spread throughout the world. On March 11, 2020, the World Health Organization (WHO) declared the outbreak as a pandemic. More than 6.3 million people in the United States have been infected with SARS-CoV-2, and 189,147 deaths from COVID-19 have been reported as of September

This work was supported by the National Institutes of Health National Institute of Neurologic Disorders and Stroke [R01NS106879] and National Institute on Drug Abuse [R01DA049737, R01DA029121].

https://doi.org/10.1124/jpet.120.000170.
9, 2020 (https://covid.cdc.gov/covid-data-tracker/\#cases). The transmission and pathogenesis of SARS-CoV-2 are shown to be, at least in part, mediated by angiotensinconverting enzyme 2 (ACE2) receptor, which is a crucial part of the renin angiotensin system (RAS)

Coronaviruses (CoVs) have been the major causes for the recent outbreaks of respiratory disease around the world. The name "coronaviruses" came about because of the viruses' shape which resembles that of a crown, as corona is the Latin for crown. CoVs are large enveloped RNA viruses with a single strand that can be isolated from a number of animal species (Perlman and Netland, 2009). These viruses can transmit into different species and cause several illnesses, which range from the common cold to severe diseases like Middle East respiratory syndrome (MERS) and severe acute respiratory syndrome. Seven human-infecting $\mathrm{CoVs}$ have been identified to date. Large type 1 transmembrane spike (S) glycoproteins give the $\mathrm{CoVs}$ their distinguishing crown-like feature. These cell surface $\mathrm{S}$ proteins are heavily glycosylated and contain two specific functional domains. These domains (S1 and S2) are hypothesized to facilitate the virus's entry into the host cell. The S1 domain contains the ACE2 receptor-binding domain and is responsible for the initial entry into the host

ABBREVIATIONS: ACE2, angiotensin-converting enzyme 2; Ang-II, angiotensin II; $\mathrm{AT}_{1} \mathrm{R}$, angiotensin type 1 receptor; BBB, blood-brain barrier; CDC, Centers for Disease Control and Prevention; CNS, central nervous system; COPD, chronic obstructive pulmonary disease; COVID-19, coronavirus disease 2019; CoV, coronavirus; e-Cig, Electronic cigarette; ICU, intensive care unit; IL, interleukin; MERS, Middle East respiratory syndrome; nAChR, nicotinic acetylcholine receptor; RAS, renin angiotensin system; SARS-CoV, severe acute respiratory syndrome coronavirus; SARS-CoV-2, severe acute respiratory syndrome coronavirus 2; WHO, World Health Organization. 
cell ( $\mathrm{Li}$ et al., 2005). The $\mathrm{S} 2$ domain helps the virus in the fusion with the cell membrane that is essential for cellular penetration (Coutard et al., 2020). Enzymatically modified S proteins expose the fusion site for cellular adhesion. Protein convertases called furin, highly expressed in the lungs, mediate this process through cleavage by cellular proteases (Follis et al., 2006; Coutard et al., 2020). SARS-CoV-2 has a diameter of approximately $60-140 \mathrm{~nm}$ with shapes ranging from round to elliptic, and it can also be pleomorphic. The genome of this virus contains 29,891 nucleotides, which encode 9860 amino acids. It has a significant level of genetic similarity with the severe acute respiratory syndrome-like CoVZXC21 found in bats and the severe acute respiratory syndrome coronavirus (SARS-CoV) found in humans (Chan et al., 2020). Hence the name SARS-CoV-2 was designated. The source of the virus could be linked with a distinct bat strain and a number of possible intermediate hosts also exist for this virus including pangolins (Zhang et al., 2020). Initially, it was thought that SARS-CoV-2 is mostly transmitted from animal to human, but later it was found that human-to-human transmission is another possible transmission route for this virus. It is mostly spread by symptomatic people, although asymptomatic spread is also possible (Qian et al., 2020). It is suggested that close contact between individuals is needed for SARS-CoV-2 spread. The transmission can occur through respiratory droplets from coughing and sneezing. Aerosol transmission is also possible in case of extended exposure to increased aerosol concentrations in closed spaces. The unique aspect of this virus is its contagiousness, expressed by its basic reproductive number, which is estimated to be between 2.2 and 2.7 (Du et al., 2020; Li et al., 2020b; Riou and Althaus, 2020), and it has an incubation period of 2-14 days. The mortality rate of COVID-19 was estimated to be $3.4 \%$ by WHO (https://www.worldometers. info/coronavirus/coronavirus-death-rate/\#who-03-03-20). Currently, no vaccine or therapeutic drug is available for SARS$\mathrm{CoV}-2$ except for remdesivir and convalescent plasma, which are approved for emergency use by the US Food and Drug Administration.

Smoking is one of the most important risk factors for aggravated COVID-19 transmission and outcome. It remains one of the primary causes of preventable diseases and death in the United States (National Center for Chronic Disease Prevention and Health Promotion Office on Smoking and Health, 2014). Although the smoking rate around the world is on the decline, there has been a recent rise of electronic cigarette (e-Cig), an alternative tobacco product, partly because of its perceived safety and widespread popularity. The short- and long-term health effects of these nicotinecontaining devices are still unknown and warrant extensive research. Since tobacco smoke and chronic vaping can cause chronic obstructive pulmonary disease (COPD), they can make people more susceptible to serious lung complications of COVID-19. Tobacco smoking and e-Cigs can also weaken lungs and the immune system, putting a person at increased risk for serious complications with COVID-19 (Bhatta and Glantz, 2020). Currently, the Centers for Disease Control and Prevention (CDC) consider people with chronic lung disease or moderate to severe asthma as at high risk for severe illness from COVID-19. A major clinical question exists related to if the CDC should place smokers and/or vapers in the high-risk category for being seriously impacted by SARS-CoV-2, even if they do not have COPD. Although clinical data comprising all epidemiologic factors are still scarce due to the ongoing progression of the pandemic, preliminary studies show a possible link between smoking and higher mortality rate in COVID-19 (Kaur et al., 2020; Vardavas and Nikitara, 2020). The act of smoking itself makes smokers likely to be more vulnerable to this disease by increasing the possibility of transmission of the virus from hand to mouth (https://www. who.int/emergencies/diseases/novel-coronavirus-2019/questionand-answers-hub/q-a-detail/q-a-on-smoking-and-covid-19). In a systematic review based on five clinical studies, Vardavas and Nikitara calculated that smokers were 1.4 times more likely to have severe symptoms of COVID-19 and approximately 2.4 times more likely to be admitted to an intensive care unit (ICU), require mechanical ventilation, or die (Vardavas and Nikitara, 2020). Also, COVID-19-associated hospitalization rates were higher in men than in women (5.1 vs. 4.1 per 100,000 population) during March 1-28, 2020 in the United States (Garg et al., 2020). These data can be potentially linked with smoking and COVID-19 mortality, as men are more likely to be current cigarette smokers (https://www.cdc.gov/tobacco/ data_statistics/fact_sheets/adult_data/cig_smoking/index.htm). Smokers have been demonstrated to be at a higher risk to contract influenza with aggravated symptoms. They were also shown to have increased mortality in the previous MERS-CoV outbreak (Arcavi and Benowitz, 2004; Park et al., 2018). Recent reports have shown that nicotine and tobacco smoke exposure can upregulate ACE2 expression in different organs of the body. In this article, we explore the role of ACE2 in COVID-19 outcome and how smoking can modulate this receptor in lung and brain, two of the most vital body organs, potentially resulting in enhanced SARS-CoV-2 infection and worsened COVID-19 prognosis and mortality rate.

\section{Pathobiology of COVID-19 in the Lungs and Brain}

The complete pathobiology of COVID-19 has not been fully elucidated. The lungs are the principal organs affected by the virus due to its airborne transmission route. Other organs in the body, e.g., heart and brain, also show signs and symptoms of direct or indirect viral injury. Cardiopulmonary symptoms are seen in the critical COVID-19 cases and can progress to acute respiratory distress syndrome, organ failure, and sepsis in severe cases due to an overactivation of the immune system termed "cytokine storm" (Guan et al., 2020a). Here, we have primarily focused on the pathologic effects of SARS-CoV-2 on the lungs and brain.

Lung. The severity of SARS-CoV-2 infection depends on the region of the lung affected. Mild symptoms involve the upper respiratory airways, whereas the severe stages of the infection occur in the lower respiratory tract. COVID-19 can be divided into three phases that correspond to different clinical stages of the disease (Mason, 2020; Wu and McGoogan, 2020). The asymptomatic stage lasts for the initial 1 to 2 days of infection when the inhaled virus attaches to the nasal epithelial cells. Individuals become infectious at this point despite having a low viral titer. The second stage involves the upper respiratory airways. The virus replicates and moves down the respiratory tract, which creates a stronger and robust immune response. The symptoms of COVID-19 are observable at this stage. Approximately $20 \%$ of the infected patients advance to the third stage of COVID-19, which is 
a severe condition characterized by pulmonary infiltrates. At this stage, the virus reaches the lower respiratory tract, the site for gaseous exchange, and induces a number of pathologic changes, which include bilateral diffuse alveolar damage, hyaline membrane formation, pulmonary edema, interstitial mononuclear inflammatory infiltrates, multinucleated syncytial cells, and amphophilic granular cytoplasm (Xu et al., 2020). Alveolar type II cells are preferentially affected over type I cells in both influenza and SARS-CoV (Mossel et al., 2008; Weinheimer et al., 2012). In a recently published study, human alveolar type II cells infected with SARS-CoV showed release of viral particles leading to cellular apoptosis and the resultant decrease of type II cells also led to secondary epithelial regeneration (Qian et al., 2013). Kumar et al. reported similar results in a murine model of influenza pneumonia (Kumar et al., 2011). Fever and dry cough are some of the most common symptoms (Chen et al., 2020; Huang et al., 2020a) that are seen at the initial stages of COVID-19. However, the most typical COVID-19 symptom is respiratory distress. Dyspnea is the marker for a severe form of the disease, which is a dangerous condition requiring immediate medical attention. Among the patients experiencing dyspnea, more than half need ICU treatment. Conditions of most patients in the ICU deteriorated, quickly resulting in death due to respiratory failure (Li et al., 2020d). Current research will help fill the pathogenesis gaps between COVID-19 damage to lungs to further improve pulmonary function for these patients and to test potential antiviral agents.

Brain. SARS-CoV-2 infection has been shown to exert different neurotropic actions (Archie and Cucullo, 2020). It has been demonstrated that $\beta-\mathrm{CoVs}$, to which SARS-CoV-2 belongs, affect the central nervous system (CNS) as well as the respiratory tract (Steardo et al., 2020). This property was seen in SARS-CoV, MERS-CoV, and the coronavirus responsible for porcine hemagglutinating encephalomyelitis. Because of the resemblance between SARS-CoV and SARS-CoV-2, it is highly probable that SARS-CoV-2 could also have a similar potential. SARS-CoV-2 can breach the blood-brain barrier (BBB) during the course of ongoing infection. Based on an epidemiologic survey, the median time from the first symptom of COVID-19 to dyspnea, hospital admission, and ICU were 5, 7, and 8 days respectively (Wang et al., 2020a). This latent period gives the virus enough time to enter the nervous system and infect the brain of patients with COVID-19. BBB disruption is more likely to happen in severe cases of the infection and can be associated with adverse immunologic reactions such as the cytokine storm (Channappanavar and Perlman, 2017; Mao et al., 2020b). The virus can remain latent in the neural cells, but it can also produce harmful neurologic symptoms affecting vascular homeostasis, adaptive immunity, and cognitive function. Neuroinvasion is hypothesized to be a potential mechanism for the pathophysiology and clinical manifestations of COVID-19 (Steardo et al., 2020), which could also play a vital role in the respiratory failure of the patients ( $\mathrm{Li}$ et al., $2020 d)$. A recent retrospective report suggests that over $30 \%$ of 814 patients with COVID-19 showed neurologic symptoms (Mao et al., 2020b). Loss of sense of smell (anosmia) frequently occurs in patients with COVID-19 (Gane et al., 2020). Furthermore, several studies have reported other neurologic signs such as nausea, vomiting, and headache ( $\mathrm{Li}$ et al., 2020d). Guan et al. found less frequent neurologic symptoms such as headache (13.6\%) and myalgias (14.9\%) in a group of 1099 SARS-CoV-2-infected patients (Guan et al., 2020b), but neurologic involvement carried a poor prognosis for patients with COVID-19. In a concurrent study, Mao et al. found that about $88 \%$ of patients with severe COVID-19 showed neurologic symptoms, which include acute cerebrovascular disorders and defective consciousness (Mao et al., 2020a). There were also reports of large vessel stroke in the SARS-CoV outbreak in Singapore in 2004 (Umapathi et al., 2004). Coagulopathy and vascular endothelial dysfunction have also been suggested as potential complications of COVID-19 (Zhou et al., 2020a). In light of that, there have been recent reports of unexplainable acute large vessel strokes in young patients with COVID-19 (Oxley et al., 2020). Five cases of large vessel stroke in patients with COVID-19 under the age of 50 were reported over 2 weeks. The stroke rate was found to be approximately $5 \%$ in a retrospective study of hospitalized patients in Wuhan, China ( $\mathrm{Li}$ et al., 2020c). The youngest patient in that study was 55 years old. Similarly, Beyrouti et al. suggested that an elevated systemic prothrombotic state could play a role in COVID-19-linked ischemic stroke incidents (Beyrouti et al., 2020).

COVID-19 may affect the nervous system by different hypothesized mechanisms, which could also overlap. It could directly affect the nervous tissue as seen with herpes simplex encephalitis. It has been hypothesized that SARS-CoV-2 can enter the nervous system via the ACE2 receptor, which is present in glial cells and neurons. Other possible mechanisms to invade the CNS include hematogenous spread and retrograde neuronal transmission via olfactory neurons in the cribriform plate (Ding et al., 2004; Gu et al., 2005; Xu et al., 2005; Netland et al., 2008). Research with the similar SARS$\mathrm{CoV}$ indicate that this virus can also directly enter the brain. Direct neuroinvasion of SARS-CoV-2 into the medullary cardiorespiratory center can contribute to the respiratory failures seen in patients with COVID-19 (Ding et al., 2004; Gu et al., 2005; Xu et al., 2005; Netland et al., 2008; Li et al., 2020d). RNAs of SARS-CoV have been found, almost exclusively in neurons, in the cerebrospinal fluid and brain tissue of SARS-CoV-infected patients (Ding et al., 2004; Gu et al., 2005; $\mathrm{Xu}$ et al., 2005), and brain penetration of SARS-CoV via the olfactory system can also happen as observed in mice (Netland et al., 2008). The brainstem was demonstrated to be heavily infected by SARS-CoV (McCray et al., 2007; Netland et al., 2008). This evidence can be linked with the olfactory and taste disorders reported in some patients with COVID-19. The second type of brain injury can occur due to an aggravated immune response, which has been described previously as a cytokine storm. Cytokines can cross the BBB and are linked with acute necrotizing encephalopathy. One such case linked with COVID-19 has been reported (Poyiadji et al., 2020). The third mechanism of CNS damage could result from untoward host immune response to an acute infection, which can be exemplified by Guillain-Barré syndrome. One case of GuillainBarré syndrome associated with COVID-19 has been reported although with limited evidence for cause and effect (Zhao et al., 2020a). The fourth mechanism of indirect viral damage results from the effects of systemic illness. Neurologic symptoms like encephalopathy, critical illness myopathy, and neuropathy are commonly seen in COVID-19. Most cases of neurologic complications linked with the disease would appear to fall into this class. 


\section{Role of ACE2 in the Transmission and Pathobiology of COVID-19}

The RAS is an important factor in the regulation of physiologic parameters including blood pressure (Xia and Lazartigues, 2008). The RAS can follow two different pathways resulting in either tissue injury or protection. The physiologic functions and interplay between different RAS components have been summarized in Fig. 1. ACE2 is a type I transmembrane metallocarboxypeptidase homologous to ACE. ACE2 was identified in 2000 (Donoghue et al., 2000; Tipnis et al., 2000) and was initially reported to be expressed in the heart, kidney, and testis (Donoghue et al., 2000; Tipnis et al., 2000). Later studies showed a ubiquitous ACE2 expression all over the body (Igase et al., 2005; Sakima et al., 2005; Doobay et al., 2007). ACE2 metabolizes angiotensin I to Ang-(1-9) and angiotensin II (Ang-II) to Ang-(1-7) (Ferrario, 2011). These metabolites exert potent vasodilator and other protective effects, mediated by the Mas receptor, which could also negatively regulate the RAS (Crackower et al., 2002; Ferrario, 2011). Our laboratory investigates the function and regulation of the brain endopeptidase neurolysin, which increases formation of Ang-(1-7) and other brain specific substrates as a potential target to preserve the brain after stroke injury (Rashid et al., 2014; Jayaraman et al., 2020). The physiologic role of ACE2 in human health is complex and has not been fully elucidated yet, but possible protective effects of ACE2 against lung injury (Imai et al., 2005) and oxidative stress (Xia et al., 2011) have been observed in experimental studies.

Both bioinformatics modeling and in vitro experiments indicate that SARS-CoV-2 likely utilizes ACE2 as a receptor to enter human cells (Zhou et al., 2020b). ACE2 was also previously identified as an entry receptor for SARS-CoV and human coronavirus NL63 (Li et al., 2007). ACE2 expression level may enhance SARS-CoV-2 binding and infectivity; this hypothesis warrants further investigation. SARS-CoV has been detected in brains of infected patients, almost exclusively in neurons, suggesting possible distribution of ACE2 to the CNS (Ding et al., 2004; Gu et al., 2005; Xu et al., 2005). The expression of ACE2 is increased significantly 24 hours after SARS-CoV infection and remains at a high level after 48 hours (Li et al., 2020a). This indicates that ACE2 not only plays a critical role in viral susceptibility but may also be involved in postinfectious regulation. The high expression of ACE2 was related to enhanced inflammatory responses, which could be linked with the symptoms of a cytokine storm. A clinical study in Wuhan also found that the levels of some proinflammatory markers, such as interleukin (IL)-1 $\beta$, IL-10, and IL-8, were significantly increased in critically ill patients with new COVID-19 infection (Huang et al., 2020a). This may be associated with pyroptosis which has been suggested as another pathologic mechanism involved in this infection. Pyroptosis is an inflammatory form of apoptosis. Li et al. found that high expression of ACE2 in lung tissue induced a cytotoxic reaction, neutrophil inflammation, and a type $2 \mathrm{~T}$ helper cell-dominated immune response. Moreover, the expression of ACE2 varies in a time-dependent manner after SARS-CoV infection. Although ACE2 has been shown to exert anti-inflammatory effects in experimental studies (Rodrigues Prestes et al., 2017), Li et al. suggested that ACE2 expression could be linked with the activation of several inflammatory mediators, including neutrophils, natural killer cells, T helper cells, dendritic cells, and tumor necrosis factor- $\alpha$-secreting cells. These events can result in an aggravated inflammatory reaction in SARS-CoV, which could be an indirect effect of the virus binding to cell surface ACE2 ( $\mathrm{Li}$ et al., 2020a).

Another potential role of ACE2 (Fig. 1), seemingly paradoxical to its role in viral transmission and inflammation in COVID-19, has been suggested in the literature (Guo et al., 2020; Li et al., 2020d). It was discovered that infection with SARS-CoV led to the downregulation of the ACE2 receptor (Glowacka et al., 2010). From a physiologic standpoint, the ACE2 receptor serves as a negative regulator of severe lung edema and lung injury by decreasing Ang-II levels (Imai et al., 2005). Ang-II-induced vascular permeability and lung injury are facilitated by binding to the angiotensin type 1 receptor $\left(\mathrm{AT}_{1} \mathrm{R}\right)$ (Jia, 2016). In a mouse model, SARS-CoV-induced lung damage was shown to be attenuated by $\mathrm{AT}_{1} \mathrm{R}$ antagonism (Kuba et al., 2005). If SARS-CoV (and possibly SARS-CoV-2) binding to ACE2 causes downregulation of ACE2, this could further result in higher Ang-II levels and increased lung injury. Multiple ACE2 knockout mouse models have demonstrated the protective effects of ACE2 from lung injury and

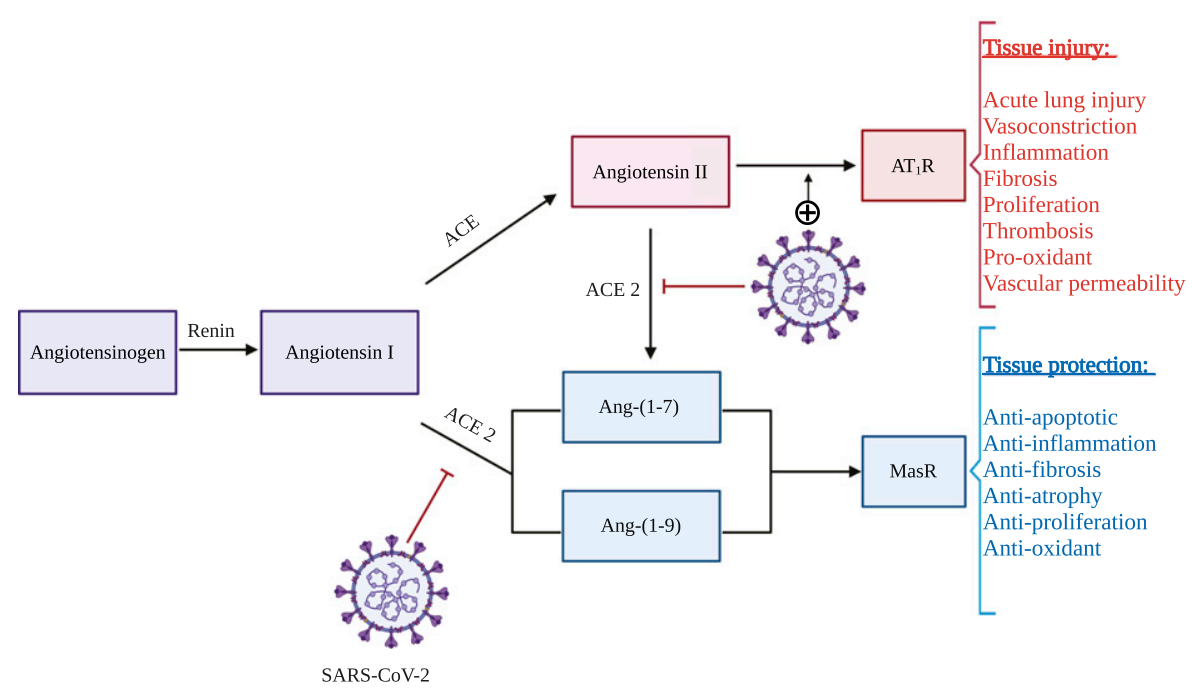

Fig. 1. Possible interactions between SARS$\mathrm{CoV}-2$ and the renin angiotensin system: SARSCoV-2 binds to cell surface ACE2 receptor with its spike protein for host cell entry. After endocytosis of the virus, surface ACE2 is downregulated but ACE remains unchanged. This event alters the balance of the RAS. Ang-II is increased and the injurious effects of this hormone (vasoconstriction, inflammation, fibrosis etc.), mediated by $\mathrm{AT}_{1} \mathrm{R}$, can result in excessive tissue damage, e.g., lung tissue damage. On the other hand, the concomitant decrease in Ang-(1-7) and Ang-(1-9) hinders the protective effects (antiapoptotic, anti-inflammation, antifibrosis etc.) of these hormones, mediated by Mas receptor (MasR), causing further tissue injury. 
vascular inflammation (Gu et al., 2016). ACE2, being a significant negative regulator of RAS in the cardiovascular system, plays a significant role in the control of blood pressure; the higher mortality in Chinese patients with COVID-19 and hypertension may be related to that phenomenon. Additionally, ACE2 null mice display reduced cardiac contractility. These results may explain why cardiac impairment is observed more frequently in patients who die from COVID-19 (Kuba et al., 2010; Thomas et al., 2010). Inhibitors of the ACE2 and RAS have been suggested as potential therapeutic strategies for COVID-19 (Vaduganathan et al., 2020). Contrastingly, it was also suggested that ACE inhibitor or $\mathrm{AT}_{1} \mathrm{R}$ blocker therapy may increase the risk and sensitivity to COVID-19 (Fang et al., 2020), but studies have not found any significant association between the use of these drugs and COVID-19 outcome and prognosis (Díaz-Guardiola et al., 2020; Huang et al., 2020b). The complex interplay of ACE2 and the RAS system on COVID-19 pathobiology has not been fully elucidated, and additional mediators or receptors other than ACE2 could assist viral binding and host entry, which warrant further investigation. There is also a hypothesis that enhanced expression of soluble ACE2 may function as a competitive interceptor of SARS-CoV-2 which can slow cellular entry of virus, thereby mediating protective effects against lung injury (Batlle et al., 2020). Although no receptor other than ACE2 has been connected with the viral binding and entry, cellular proteases can play an important role in the cellular entry of SARS-CoV-2 by facilitating viral activation and engulfment. These include the transmembrane protein serine 2 (Leung et al., 2020), cathepsin B/L (Sungnak et al., 2020), and serine protease inhibitors (serpins) (Dittmann et al., 2015), which need to be investigated for any potential benefits in COVID-19. Moreover, combination therapies targeting multiple mechanisms of the viral entry into the host cell may provide better therapeutic efficacy.

\section{Smoking and Vaping: Possible Risk Factors for COVID-19}

The severity of COVID-19 outcome can be affected by various risk factors and coexisting conditions. Age, cardiovascular diseases, chronic COPD, asthma, pulmonary fibrosis and interstitial lung disease, type 1 and type 2 diabetes are all shown to be potential risk factors for worsened COVID-19 outcomes (Leung et al., 2020; Mason, 2020). Another potential risk factor, which can affect the clinical outcome of COVID-19 is smoking, but this is not listed as a CDC risk factor. A review of studies by public health specialists, which was convened by WHO on April 29, 2020 found that smokers are more vulnerable to develop severe COVID-19 compared with nonsmokers (https://www.who.int/news-room/detail/11-05-2020who-statement-tobacco-use-and-covid-19). Another recent meta-analysis established an association between smoking and COVID-19 (Patanavanich and Glantz, 2020). Smoking is a crucial factor in determining a person's ability to develop and manage viral infection, especially a respiratory infection (Razani-Boroujerdi et al., 2004; Eddleston et al., 2011). Smokers have more respiratory diseases, including colds, than nonsmokers. The influenza rate is double in smokers and they have also enhanced rates of bacterial pneumonia and tuberculosis (Atto et al., 2019; Eapen et al., 2019).
Cigarette smoking is the leading cause of premature death in the world (Jha, 2009). Smoking can also enhance the risk for other risk factors for COVID-19. It is also the single most important risk factor for the development of cardiovascular and pulmonary diseases and smokers are two to four times more likely to develop cardiovascular and pulmonary diseases than nonsmokers (National Center for Chronic Disease Prevention and Health Promotion Office on Smoking and Health, 2014; Jamal et al., 2018). A causal relationship has been established between smoking and coronary heart disease, atherosclerotic aortic aneurysm, cerebrovascular disease, stroke, acute respiratory illnesses, COPD, and exacerbation of asthma (National Center for Chronic Disease Prevention and Health Promotion Office on Smoking and Health, 2014). Cigarette smoking has been in a steady decline since the $1950 \mathrm{~s}$, but the introduction of e-Cig 10 years ago has gained interest from former smokers as well as a new generation of consumers. Nicotine is a highly addictive substance, and it is currently unclear whether e-Cig use, commonly known as vaping, is "safer" than regular cigarette use or whether vaping can overturn the health gains, mostly on the cardiopulmonary system, achieved with the reduction of tobacco smoking. It is a matter of significant concern that nicotine inhalation devices are becoming increasingly popular in the young generation (Wagoner et al., 2016), which calls for greater awareness and more investigations into the potential cardiopulmonary risks of nicotine-containing products. Not enough attention has been given to the role of smoking in either the transmission of the novel SARS-CoV-2 or COVID-19 mortality rate (Brake et al., 2020). Smokers have higher susceptibility to COVID-19, as the act of smoking itself enhances the possibility of virus transmission from hand to mouth (https://www.who.int/ emergencies/diseases/novel-coronavirus-2019/question-andanswers-hub/q-a-detail/q-a-on-smoking-and-covid-19\#). Furthermore, smoking-induced lung injury enhances susceptibility to viral and bacterial pulmonary infections (Lawrence et al., 2019). Preclinical research studies have associated e-Cig exposure with increased pulmonary inflammation, oxidative stress, inhibition of the immune system, mucus hypersecretion, and protease-mediated lung damage, which is a similar pathogenesis seen from exposure to combustible tobacco products (Moretto et al., 2012; Chun et al., 2017). A recent longitudinal analysis also showed that e-Cig use, like combustible tobacco smoking, is a separate risk factor for respiratory diseases (Flacco et al., 2020). Interestingly, dual use (e-Cig and combustible tobacco products) was the most common usage trend and was found to be riskier than using a single product. WHO reported that a significant number of COVID-19-related deaths are linked with comorbid conditions (Zheng et al., 2020). Smoking can also negatively impact the severity of COVID-19 outcome by interaction with the RAS system. Table 1 lists retrospective observational studies that established a correlation between smoking and COVID-19 severity and/or mortality.

\section{Effects of Smoking on COVID-19: Role of Nicotinic Acetylcholine Receptors and ACE2 Receptors}

Nicotine and smoking exposure can modulate ACE2 expression in the lungs and other major organs of the body, which 


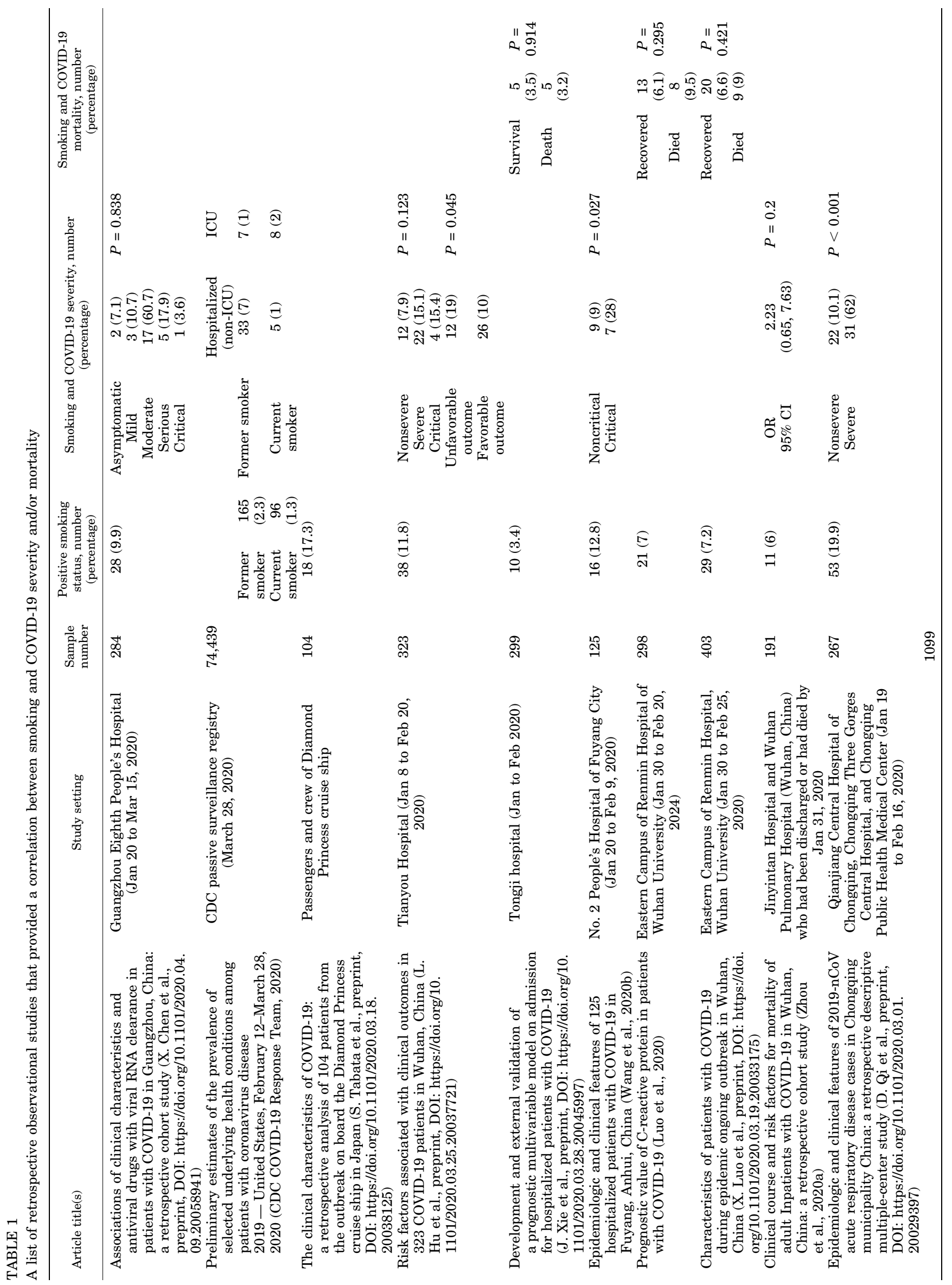

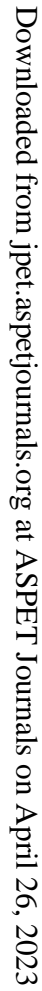


suggests that smoking could promote COVID-19 cellular entry through nicotinic acetylcholine receptor (nAChR) signaling. nAChRs are found in cells that also express ACE2 in the lungs, kidneys, heart, brain, and other organs (Changeux, 2010; Tolu et al., 2013; Nordman et al., 2014). Smoking can thus affect the pathogenesis and prognosis of COVID-19 in many organs.

Lung. Nicotine inhaled from tobacco smoke or e-Cig first exerts its action on the lung. nAChRs are expressed in different lung cell types, which include type II alveolar epithelial cells, alveolar macrophages, bronchial epithelial cells, interstitial fibroblasts, and pulmonary endothelial cells (Conti-Fine et al., 2000; Oakes et al., 2018). These cell types also express the RAS components.

Studies have provided suggestions that smoking and vaping may increase the risk of SARS-CoV-2 infections, although these have not been directly proven yet (Lockett et al., 2012; Jackson et al., 2020; Smith and Sheltzer, 2020). Some contrasting studies have even shown a lower prevalence of smoking in patients with COVID-19 (K. Farsalinos et al., preprint, DOI: https://doi.org/10.32388/Z69O8A.13; Tajlil et al., 2020). Researchers have also demonstrated that smokers may have a worsened outcome of COVID-19 after contracting the virus (Del Sole et al., 2020; Kaur et al., 2020). Nicotine can functionally and quantitatively enhance lung ACE. Li et al. found that ACE2 level was markedly upregulated in long-term smokers ( $\mathrm{Li}$ et al., 2020a). Smokers and individuals with COPD are also shown to have an increased airway expression of ACE2. These results are consistent with previous studies in rodents that showed that smoke exposure upregulated both the expression and activity of airways' ACE2 (Yilin et al., 2015; Hung et al., 2016). Although the upregulation of ACE2 may play a beneficial role in protecting the host against acute lung damage, with chronic exposure, this may create an enhanced risk of $\mathrm{CoV}$ infections in smokers. This would partially account for the enhanced susceptibility of active smokers to viral respiratory tract infection and also virus-induced complications in smokers who had COPD. Researchers, using an ex vivo lung perfusion model, showed that smoking exposure for 1 day increased the conversion of angiotensin I to Ang-II in rats (Bakhle et al., 1979). In a recent study, Cai et al. also showed an enhanced pulmonary ACE2 gene expression in smokers (Cai et al., 2020). They also showed that furin, the protein convertase, was upregulated in the lungs by smoking. This study observed that smoking induces hyperplasia of goblet cells and a reduction of club cells in the bronchial epithelium. ACE2 gene was also shown to be primarily expressed in goblet cells in smokers and club cells in never smokers. This result is consistent with another very recent study that found that ACE2 is mostly expressed in club cell-derived Alveolar type II cells and in a transient secretory cell type in subsegmental bronchial branches (Lukassen et al., 2020). Brake et al. observed a higher ACE2 level in smokers' lungs with or without COPD (Brake et al., 2020). ACE2 was notably expressed in patients with COPD, which suggests that COPD can further exaggerate ACE2 and expose possible SARS-CoV-2 attachment sites. Results from previous studies showed that attachment of SARS-CoV-2 to ACE2 could in turn decrease ACE2 expression. Consequently, other relevant ACE enzymes were upregulated causing severe acute respiratory failure (Kuba et al., 2005; Zhao et al., 2020b). Wang et al. also concluded that ACE2 could be linked with COVID-19 and smoking (J. Wang et al., preprint, DOI: https://doi.org/10. 
20944/preprints202003.0078.v1). Another study demonstrated dose-dependent upregulation of ACE2 by smoking in rodent and human lungs (Smith and Sheltzer, 2020). They also showed that chronic smoking causes hyperplasia of goblet cells in the respiratory epithelium, which was linked with enhanced ACE2 expression. Furthermore, ACE2 is shown to be significantly expressed in type 2 pneumocytes that have a high expression of genes regulating viral reproduction and transmission (Brake et al., 2020; Zhao et al., 2020b). Researchers (Podowski et al., 2012) demonstrated that chronic cigarette smoke exposure with losartan treatments showed a protective action against the injurious effects exerted by smoking exposure, which include enhanced oxidative stress in lung, emphysema, fibrosis, and apoptosis of alveolar septal cell in mice. In this study, cigarette smoke upregulated $\mathrm{AT}_{1} \mathrm{R}$ expression in the lung parenchyma, which was reversed by losartan. The ratio of $\mathrm{AT}_{1} \mathrm{R}$ to angiotensin type 2 receptor $\left(\mathrm{AT}_{2} \mathrm{R}\right)$ increased 5-6-fold in bronchiole areas with enhanced fibrosis, which were associated with diminished lung function in patients with COPD (Bullock et al., 2001). A recent study also showed that subchronic e-Cig exposure enhances lung inflammation and ACE2 expression, which were shown to be mediated by $\alpha 7 \mathrm{nAChRs} \mathrm{(Q.} \mathrm{Wang} \mathrm{et} \mathrm{al.,} \mathrm{preprint,} \mathrm{DOI:} \mathrm{https://doi.org/10.}$ 21203/rs.2.23829/v2). Maremanda et al. have demonstrated that transcriptional changes in genes regulating mitochondrial activity, cellular senescence, and telomere length might contribute to smoking-related chronic lung disorders in association with COVID-19 infection (K. P. Maremanda et al., preprint, DOI: https://doi.org/10.1101/2020.06.14.20129957). These results indicate that smokers and/or vapers may have an increased risk of COVID-19-related complications that can aggravate disease severity and treatment outcome.

It is important to note that although smokers with significant lung disorders are more sensitive to worsened prognosis of COVID-19, evidence of similar worsening effects in healthy smokers has been scarce. Studies involving patients with COVID-19 in China have also shown that smoking prevalence in patients with COVID-19 was lower than the estimated expected prevalence (K. Farsalinos et al., preprint, DOI: https://doi.org/10.32388/Z69O8A.13). Confounding factors must be carefully considered when interpreting these findings, including the absence of control groups and the descriptive nature of the studies. Also, inherent differences in demographic variables of the populations could make a comparison between the smoking prevalence in hospitalized patients with COVID-19 and that of overall population estimates inappropriate (Reddy et al., 2020). Researchers have further suggested possible beneficial effects of nicotine in COVID-19 (Farsalinos et al., 2020). These effects are thought to be mediated by the anti-inflammatory effects of nicotine (Ulloa, 2005; Mabley et al., 2011) by its interaction with the cholinergic nervous system, notably $\alpha 7$ nAChRs. Exploring the potential of nicotine as a therapeutic agent in the treatment of COVID-19 seems intriguing; however, with respect to smoking/vaping, these suggestions should be carefully examined, since acute and chronic exposures and multiple doses of nicotine might alter the observed beneficial effects on the cholinergic nervous system. Moreover, the proinflammatory effects of other components of tobacco smoke/e-Cig could offset any beneficial effects exerted by nicotine. Contrary to this notion, a recent study by Wang et al. showed that nicotine-containing e-Cig exposure can increase the level of inflammatory mediators in the lung, which was mediated by $\alpha 7$ nAChRs (Q. Wang et al., preprint, DOI: https://doi.org/10.21203/rs.2.23829/v2). Further studies are definitely warranted to determine the effects of nicotine on inflammation.

Brain. Nicotine primarily exerts its brain effects by binding to neuronal nAChRs, which are omnipresent throughout the CNS and play a crucial role in neuronal excitation in autonomic ganglia (Dani and Bertrand, 2007). Nicotine could affect autonomic nuclei by interacting with the brain RAS (Xu et al., 2011). Furthermore, exposure to nicotine is shown to alter both the expression and the activity of the brain RAS system. Perinatal nicotine exposure is also demonstrated to alter the brain RAS, resulting in enhanced sympathetic function in the adult offspring. Baroreflex sensitivity was decreased after Ang-II infusion in rats that were prenatally exposed to nicotine (Xiao et al., 2008; Yu et al., 2017). Perinatal nicotine exposure can also increase brain $\mathrm{AT}_{1} \mathrm{R}$ and decrease brain $\mathrm{AT}_{2}$ Rexpression in offspring rats (Lu et al., 2008). ACE2, the target receptor of SARS-CoV-2, is found in the brain and shown to functionally modulate nAChRs (Ferrari et al., 2007; Oakes et al., 2018). ACE2 signaling is hypothesized to act as a counteractive mechanism against oxidative stress and neuroinflammation. It also counteracts the impairment of the activity and stability of ACE that can lead to enhanced neurodegenerative loss of dopaminergic neurons (Labandeira-García et al., 2014). Impaired ACE activity could affect cholinergic pathways in the brain cortex and can thereby play a role in Alzheimer's disease progression (Kehoe et al., 2009). Significant ACE2 mRNA expression was found in different regions of the adult human brain (Jones et al., 2009), which also express various nAChR subtypes (Dani and Bertrand, 2007). Our laboratory has further shown that long-term nicotine exposure can upregulate neuronal $\alpha 7$ nAChR in ischemic condition (Sifat et al., 2018). These make smokers' brain cells more susceptible to the infection, as nicotine can upregulate ACE2 expression of these cells through the nAChRs (Olds and Kabbani, 2020). This is a significant matter to consider, as mRNA analysis of infected patients reveals that the similar SARS-CoV, which also uses ACE2 to enter the host cell, was present in the brain and cerebrospinal fluid (Zhang et al., 2003; Chong et al., 2004; Inoue et al., 2007). Additionally, the capacity of SARS-CoV to enter neurons has been shown previously (Netland et al., 2008; Kaparianos and Argyropoulou, 2011). Virtually every systemic RAS component is present in the brain (Xu et al., 2011; Oakes et al., 2018). As Ang-II cannot easily enter the brain because of the BBB, the function of brain RAS is not dependent on the systemic RAS (Schelling et al., 1976). Endogenous Ang-II has been detected in different brain regions, including hypothalamus and brainstem (Lind et al., 1985). Figure 2 outlines a possible mechanistic pathway through which nicotine can upregulate ACE2 receptor expression to facilitate the entry of SARS-CoV-2 in neurons, resulting in different neurologic complications. Although several studies involving smoking and lung ACE2 expression have been conducted, effects of smoking and vaping on brain ACE2 expression are scarce, which warrants further investigations to explore the role of smoking in neurologic and cerebrovascular complications of COVID-19.

COVID-19 can cause unexplained and abnormal blood coagulation leading to large vessel stroke in young people, as 


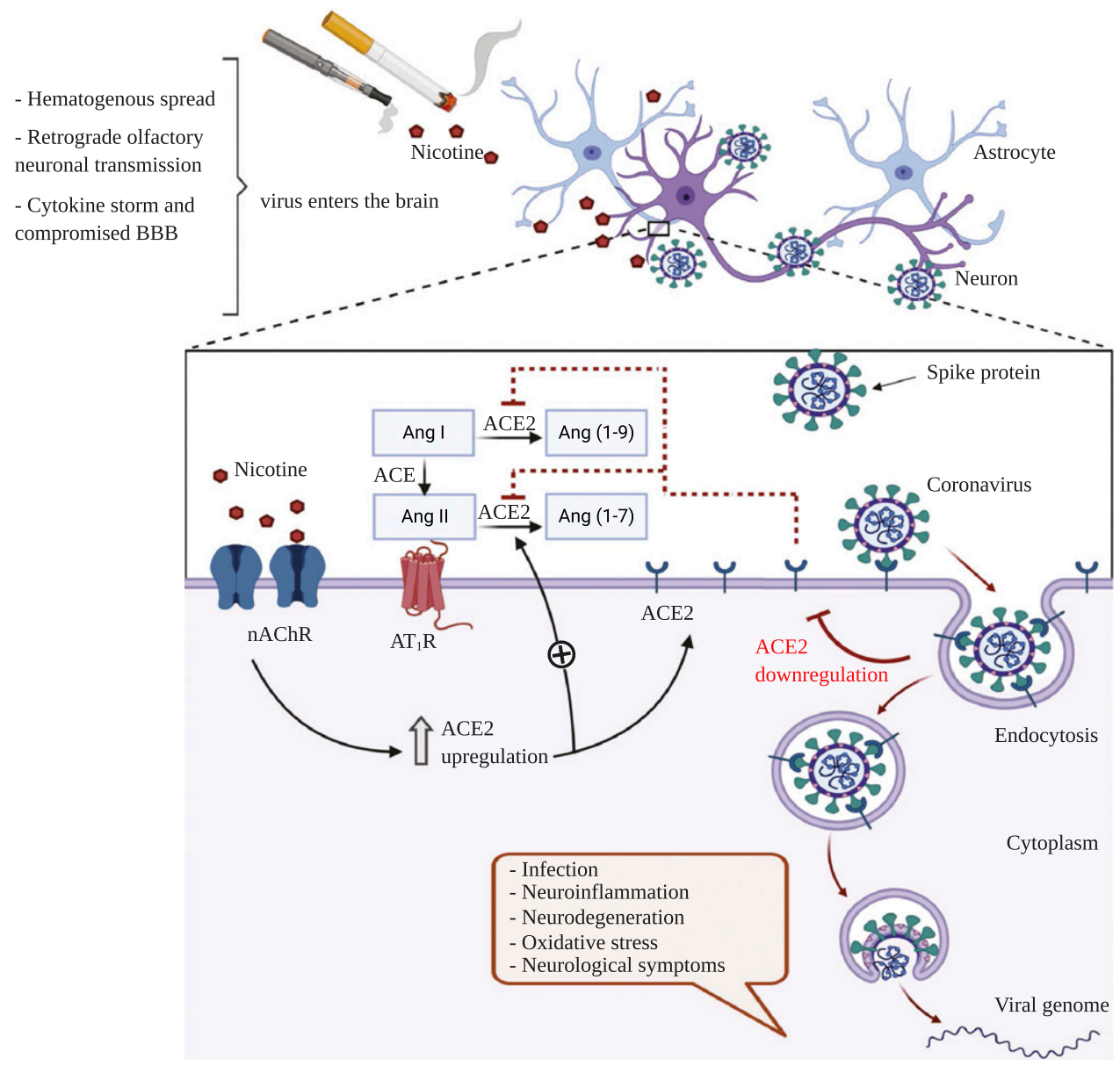

Fig. 2. Hypothetical mechanism of nicotine-induced facilitation of SARSCoV-2 entry into neurons through ACE2 receptors: SARS-CoV-2 can enter the central nervous system through different mechanism(s) (hematogenous spread, retrograde olfactory neuronal transmission, cytokine storm, and compromised bloodbrain barrier) and bind to its proposed receptor, ACE2, almost exclusively in neurons. The virus then enters the neurons through endocytosis and starts replication, which could lead to a number of neurologic complications. In the brain, nicotine acts by binding to neuronal nAChRs and also interacts with the brain RAS. Nicotine exposure results in an upregulation of nAChRs, which can subsequently increase cell surface ACE2 expression. Excessive ACE2 could competitively bind with SARS-CoV-2 and enhance the viral entry and replication in neurons. This enhanced viral binding to ACE2 could in turn downregulate the expression of ACE2 receptor causing an imbalance in the brain RAS. As a result, the detrimental effects of Ang-II, mediated by $\mathrm{AT}_{1} \mathrm{R}$, would be increased, whereas the protective effects of Ang(1-7) and Ang-(1-9), mediated by Mas receptor (MasR), would be decreased. The overall effects of these mechanisms could result in an excessive neuronal infection and damage by SARS-CoV-2.

mentioned earlier. Tobacco smoke and/or e-Cig exposure can potentially worsen that complication. Our laboratory and others have previously shown that nicotine and tobacco smoke exposure can worsen ischemic stroke outcome (Paulson et al., 2006, 2010; Kaisar et al., 2017; Matsuo et al., 2020). We have specifically shown that tobacco smoke or e-Cig exposure can downregulate circulating thrombomodulin level, which suggests a procoagulant predisposition and increased risk of stroke (Kaisar et al., 2017). Nicotine and tobacco smoke exposure are also associated with aggravated brain inflammation and oxidative stress and also reduced brain glucose utilization in ischemic stroke conditions (Kaisar et al., 2017; Sifat et al., 2018). On top of these, e-Cig is becoming increasingly popular among the young generation because of its perceived safety and lack of proper education (Murthy, 2017). Rigorous research is needed to elucidate the link between largevessel stroke and young patients with COVID-19 and how smoking and/or vaping can potentially modulate this interaction, possibly through ACE2 receptors.

\section{Conclusion}

COVID-19 is the most recent global pandemic that has already caused over 894,983 deaths worldwide. Due to the fast human to human contagiousness of the SARS-CoV-2 virus, cases have easily spread from China to the whole world. People all over the world are being home quarantined and maintaining social distance to fight off the contraction of this virus. There is a dire need for preventive vaccines and therapeutic agents for battling this worldwide pandemic. The US Food and Drug Administration has approved emergency use authorizations for remdesivir and convalescent plasma for the treatment of COVID-19 in hospitalized patients. Several other potential therapeutics and vaccines are under investigation and development. This review explores the possible role of smoking and/or e-Cig usage in the transmission, pathobiology, and prognosis of COVID-19. We have focused on the mechanistic pathways involving nicotine and ACE2 receptors of the brain and lung RAS system, which appear to play a significant role in virus entry and COVID-19 pathobiology in humans. Research has shown that smoking and possibly e-Cig exposure can upregulate the ACE2 receptors in the brain and lung, which make smokers more vulnerable to COVID-19. Coexisting conditions are identified as significant risk factors for COVID-19 mortality. This accentuates the link between smoking and COVID-19 vulnerability as smoking is already established to increase the risk for several comorbidities including diabetes, cardiovascular disease, and COPD (Rojewski et al., 2016). The association between smoking and the risk for enhanced SARS-CoV-2 infection should be investigated further with better study design adjusting for confounding factors. The mechanisms underlying smoking mediated upregulation of ACE2 pulmonary expression are not fully understood yet, which warrants further investigations. Genetic polymorphisms of ACE2 should also be taken into consideration with respect to smoking/vaping-linked COVID-19 vulnerability, sensitivity, 
and clinical prognosis. Although the popularity of e-Cigs is on the rise, few studies have explored the effects of e-Cig exposure on lung and brain ACE2 expression. Further research involving possible injurious effects of smoking on COVID-19 outcomes should also include e-Cigs and other alternative smoking devices like waterpipes and "heat-not-burn" devices, such as "I quit original smoking" devices. Furthermore, as SARS-CoV-2 has the potential to invade the brain and cause various neurologic and cerebrovascular complications, postmortem brains of patients with COVID-19, both smokers and nonsmokers, should be analyzed whenever possible. Continuous monitoring for evidence of viral injury beyond the lungs, heart, and kidney is also required. We also propose that rigorous research should be directed toward ACE2 as it has the potential to be a valuable therapeutic target for SARSCoV-2. Especially, the interplay between ACE2 and nAChRs in the lungs and brain should be carefully investigated. Pathogenesis of large vessel ischemic stroke in smoking and nonsmoking patients with COVID-19 is another crucial research area. Importantly, people should consider taking the necessary steps to reduce smoking and vaping rates, as smoking can aggravate transmission, pathobiology, and disease outcomes of COVID-19.

\section{Authorship Contributions}

Wrote or contributed to the writing of the manuscript: Sifat, Nozohouri, Villalba, Vaidya, Abbruscato.

\section{References}

Arcavi L and Benowitz NL (2004) Cigarette smoking and infection. Arch Intern Med 164:2206-2216.

Archie SR and Cucullo L (2020) Cerebrovascular and neurological dysfunction under the threat of COVID-19: is there a comorbid role for smoking and vaping? Int $J$ Mol Sci 21:3916.

Atto B, Eapen MS, Sharma P, Frey U, Ammit AJ, Markos J, Chia C, Larby J, Haug G, Weber HC, et al. (2019) New therapeutic targets for the prevention of infectious acute exacerbations of COPD: role of epithelial adhesion molecules and inflammatory pathways. Clin Sci (Lond) 133:1663-1703.

Bakhle YS, Hartiala J, Toivonen H, and Uotila P (1979) Effects of cigarette smoke on the metabolism of vasoactive hormones in rat isolated lungs. Br J Pharmacol 65: 495-499.

Batlle D, Wysocki J, and Satchell K (2020) Soluble angiotensin-converting enzyme 2: a potential approach for coronavirus infection therapy? Clin Sci (Lond) 134: 543-545.

Beyrouti R, Adams ME, Benjamin L, Cohen H, Farmer SF, Goh YY, Humphries F, Jäger HR, Losseff NA, Perry RJ, et al. (2020) Characteristics of ischaemic stroke associated with COVID-19. J Neurol Neurosurg Psychiatry 91:889-891.

Bhatta DN and Glantz SA (2020) Association of E-cigarette use with respiratory disease among adults: a longitudinal analysis. Am J Prev Med 58:182-190.

Brake SJ, Barnsley K, Lu W, McAlinden KD, Eapen MS, and Sohal SS (2020) Smoking upregulates angiotensin-converting enzyme-2 receptor: a potential adhesion site for novel coronavirus SARS-CoV-2 (covid-19). J Clin Med 9:841.

Bullock GR, Steyaert I, Bilbe G, Carey RM, Kips J, De Paepe B, Pauwels R, Praet M, Siragy HM, and de Gasparo M (2001) Distribution of type-1 and type-2 angiotensin receptors in the normal human lung and in lungs from patients with chronic obstructive pulmonary disease. Histochem Cell Biol 115:117-124.

Cai G, Bossé Y, Xiao F, Kheradmand F, and Amos CI (2020) Tobacco smoking increases the lung gene expression of ACE2, the receptor of SARS-CoV-2. Am $J$ Respir Crit Care Med 201:1557-1559.

CDC COVID-19 Response Team (2020) Preliminary estimates of the prevalence of selected underlying health conditions among patients with coronavirus disease 2019 - United States, February 12-March 28, 2020. MMWR Morb Mortal Wkly Rep 69:382-386.

Chan JF, Kok KH, Zhu Z, Chu H, To KK, Yuan S, and Yuen KY (2020) Genomic characterization of the 2019 novel human-pathogenic coronavirus isolated from a patient with atypical pneumonia after visiting Wuhan. Emerg Microbes Infect 9: 221-236.

Changeux J-P (2010) Nicotine addiction and nicotinic receptors: lessons from genetically modified mice. Nat Rev Neurosci 11:389-401.

Channappanavar R and Perlman S (2017) Pathogenic human coronavirus infections: causes and consequences of cytokine storm and immunopathology. Semin Immunopathol 39:529-539.

Chen N, Zhou M, Dong X, Qu J, Gong F, Han Y, Qiu Y, Wang J, Liu Y, Wei Y, et al. (2020) Epidemiological and clinical characteristics of 99 cases of 2019 novel coronavirus pneumonia in Wuhan, China: a descriptive study. Lancet 395:507-513.

Chong PY, Chui P, Ling AE, Franks TJ, Tai DY, Leo YS, Kaw GJ, Wansaicheong G, Chan KP, Ean Oon LL, et al. (2004) Analysis of deaths during the severe acute respiratory syndrome (SARS) epidemic in Singapore: challenges in determining a SARS diagnosis. Arch Pathol Lab Med 128:195-204.

Chun LF, Moazed F, Calfee CS, Matthay MA, and Gotts JE (2017) Pulmonary toxicity of e-cigarettes. Am J Physiol Lung Cell Mol Physiol 313:L193-L206.

Conti-Fine BM, Navaneetham D, Lei S, and Maus AD (2000) Neuronal nicotinic receptors in non-neuronal cells: new mediators of tobacco toxicity? Eur $J$ Pharmacol 393:279-294.

Coutard B, Valle C, de Lamballerie X, Canard B, Seidah NG, and Decroly E (2020) The spike glycoprotein of the new coronavirus 2019-nCoV contains a furin-like cleavage site absent in $\mathrm{CoV}$ of the same clade. Antiviral Res 176:104742.

Crackower MA, Sarao R, Oudit GY, Yagil C, Kozieradzki I, Scanga SE, Oliveira-dosSantos AJ, da Costa J, Zhang L, Pei Y, et al. (2002) Angiotensin-converting enzyme 2 is an essential regulator of heart function. Nature 417:822-828.

Dani JA and Bertrand D (2007) Nicotinic acetylcholine receptors and nicotinic cholinergic mechanisms of the central nervous system. Annu Rev Pharmacol Toxicol 47:699-729.

Del Sole F, Farcomeni A, Loffredo L, Carnevale R, Menichelli D, Vicario T, Pignatelli P, and Pastori D (2020) Features of severe COVID-19: a systematic review and meta-analysis. Eur J Clin Invest 50:e13378.

Díaz-Guardiola P, Martín-Borge V, García-Fernández C, Ramírez-Prieto MT, Ramírez-Belmar MI, García-Romero G, de la Calle E, and Balsa JA (2020) Association of use of angiotensin-converting enzyme inhibitors and angiotensin II receptor blockers with coronavirus disease 2019 severity and mortality. American Journal of Internal Medicine 8:204-210.

Ding Y, He L, Zhang Q, Huang Z, Che X, Hou J, Wang H, Shen H, Qiu L, Li Z, et al. (2004) Organ distribution of severe acute respiratory syndrome (SARS) associated coronavirus (SARS-CoV) in SARS patients: implications for pathogenesis and virus transmission pathways. J Pathol 203:622-630.

Dittmann M, Hoffmann H-H, Scull MA, Gilmore RH, Bell KL, Ciancanelli M, Wilson SJ, Crotta S, Yu Y, Flatley B, et al. (2015) A serpin shapes the extracellular environment to prevent influenza A virus maturation. Cell 160:631-643.

Donoghue M, Hsieh F, Baronas E, Godbout K, Gosselin M, Stagliano N, Donovan M, Woolf B, Robison K, Jeyaseelan R, et al. (2000) A novel angiotensin-converting enzyme-related carboxypeptidase (ACE2) converts angiotensin I to angiotensin 19. Circ Res 87:E1-E9.

Doobay MF, Talman LS, Obr TD, Tian X, Davisson RL, and Lazartigues E (2007) Differential expression of neuronal ACE2 in transgenic mice with overexpression of the brain renin-angiotensin system. Am J Physiol Regul Integr Comp Physiol 292: R373-R381.

Du Z, Wang L, Cauchemez S, Xu X, Wang X, Cowling BJ, and Meyers LA (2020) Risk for transportation of coronavirus disease from Wuhan to other cities in China. Emerg Infect Dis 26:1049-1052.

Eapen MS, Sharma P, and Sohal SS (2019) Mitochondrial dysfunction in macrophages: a key to defective bacterial phagocytosis in COPD. Eur Respir $J$ 54: 1901641

Eddleston J, Lee RU, Doerner AM, Herschbach J, and Zuraw BL (2011) Cigarette smoke decreases innate responses of epithelial cells to rhinovirus infection. Am $J$ Respir Cell Mol Biol 44:118-126.

Fang L, Karakiulakis G, and Roth M (2020) Are patients with hypertension and diabetes mellitus at increased risk for COVID-19 infection? Lancet Respir Med 8:e21.

Farsalinos K, Niaura R, Le Houezec J, Barbouni A, Tsatsakis A, Kouretas D, Vantarakis A, and Poulas K (2020) Editorial: nicotine and SARS-CoV-2: COVID-19 may be a disease of the nicotinic cholinergic system. Toxicol Rep 7:658-663.

Ferrari MF, Raizada MK, and Fior-Chadi DR (2007) Nicotine modulates the reninangiotensin system of cultured neurons and glial cells from cardiovascular brain areas of Wistar Kyoto and spontaneously hypertensive rats. J Mol Neurosci 33: $284-293$.

Ferrario CM (2011) ACE2: more of Ang-(1-7) or less Ang II? Curr Opin Nephrol Hypertens 20:1-6.

Flacco ME, Fiore M, Acuti Martellucci C, Ferrante M, Gualano MR, Liguori G, Bravi F, Pirone GM, Marzuillo C, and Manzoli L (2020) Tobacco vs. electronic cigarettes: absence of harm reduction after six years of follow-up. Eur Rev Med Pharmacol Sci 24:3923-3934.

Follis KE, York J, and Nunberg JH (2006) Furin cleavage of the SARS coronavirus spike glycoprotein enhances cell-cell fusion but does not affect virion entry. $\mathrm{Vi}$ rology 350:358-369.

Gane SB, Kelly C, and Hopkins C (2020) Isolated sudden onset anosmia in COVID-19 infection. A novel syndrome? Rhinology 58:299-301.

Garg S, Kim L, Whitaker M, O'Halloran A, Cummings C, Holstein R, Prill M, Chai SJ, Kirley PD, Alden NB, et al. (2020) Hospitalization rates and characteristics of patients hospitalized with laboratory-confirmed coronavirus disease 2019 . COVID-NET, 14 States, March 1-30, 2020. MMWR Morb Mortal Wkly Rep 69: 458-464.

Glowacka I, Bertram S, Herzog P, Pfefferle S, Steffen I, Muench MO, Simmons G, Hofmann H, Kuri T, Weber F et al. (2010) Differential downregulation of ACE2 by the spike proteins of severe acute respiratory syndrome coronavirus and human coronavirus NL63. J Virol 84:1198-1205.

Gu H, Xie Z, Li T, Zhang S, Lai C, Zhu P, Wang K, Han L, Duan Y, Zhao Z, et al. (2016) Angiotensin-converting enzyme 2 inhibits lung injury induced by respiratory syncytial virus. Sci Rep 6:19840.

Gu J, Gong E, Zhang B, Zheng J, Gao Z, Zhong Y, Zou W, Zhan J, Wang S, Xie Z, et al. (2005) Multiple organ infection and the pathogenesis of SARS. J Exp Med 202 $415-424$

Guan WJ, Liang WH, Zhao Y, Liang HR, Chen ZS, Li YM, Liu XQ, Chen RC, Tang CL, Wang T, et al.; China Medical Treatment Expert Group for COVID-19 (2020a) Comorbidity and its impact on 1590 patients with COVID-19 in China: a nationwide analysis. Eur Respir $J$ 55:2000547.

Guan WJ, Ni ZY, Hu Y, Liang WH, Ou CQ, He JX, Liu L, Shan H, Lei CL, Hui DSC, et al.; China Medical Treatment Expert Group for Covid-19 (2020b) Clinical characteristics of coronavirus disease 2019 in China. N Engl J Med 382:1708-1720. 
Guo J, Huang Z, Lin L, and Lv J (2020) Coronavirus disease 2019 (COVID-19) and cardiovascular disease: a viewpoint on the potential influence of angiotensin-converting enzyme inhibitors/angiotensin receptor blockers on onset and severity of severe acute respiratory syndrome coronavirus 2 infection. J Am Heart Assoc 9:e16219.

Huang C, Wang Y, Li X, Ren L, Zhao J, Hu Y, Zhang L, Fan G, Xu J, Gu X, et al. (2020a) Clinical features of patients infected with 2019 novel coronavirus in Wuhan, China. Lancet 395:497-506.

Huang W, Li T, Ling Y, Qian ZP, Zhang YY, Huang D, Xu SB, Liu XH, Xia L, Yang Y, et al. (2020b) [Effects of angiotensin converting enzyme inhibitor/angiotensin re ceptor blocker on clinical characteristics of coronavirus disease 2019 patients with hypertension]. Zhonghua Nei Ke Za Zhi 59:689-694.

Hung YH, Hsieh WY, Hsieh JS, Liu FC, Tsai CH, Lu LC, Huang CY, Wu CL, and Lin CS (2016) Alternative roles of STAT3 and MAPK signaling pathways in the MMPs activation and progression of lung injury induced by cigarette smoke exposure in ACE2 knockout mice. Int $J$ Biol Sci 12:454-465.

Igase M, Strawn WB, Gallagher PE, Geary RL, and Ferrario CM (2005) Angiotensin II AT1 receptors regulate ACE2 and angiotensin-(1-7) expression in the aorta of spontaneously hypertensive rats. Am J Physiol Heart Circ Physiol 289: H1013-H1019.

Imai Y, Kuba K, Rao S, Huan Y, Guo F, Guan B, Yang P, Sarao R, Wada T, Leong-Poi $\mathrm{H}$, et al. (2005) Angiotensin-converting enzyme 2 protects from severe acute lung failure. Nature 436:112-116.

Inoue $\mathrm{Y}$, Tanaka N, Tanaka $\mathrm{Y}$, Inoue $\mathrm{S}$, Morita $\mathrm{K}$, Zhuang $\mathrm{M}$, Hattori $\mathrm{T}$, and Sugamura K (2007) Clathrin-dependent entry of severe acute respiratory syndrome coronavirus into target cells expressing ACE2 with the cytoplasmic tail deleted. J Virol 81:8722-8729.

Jackson SE, Brown J, Shahab L, Steptoe A, and Fancourt D (2020) COVID-19, smoking and inequalities: a study of 53002 adults in the UK. Tob Control DOI 10.1136/tobaccocontrol-2020-055933 [published ahead of print].

Jamal A, Phillips E, Gentzke AS, Homa DM, Babb SD, King BA, and Neff LJ (2018) Current cigarette smoking among adults - United States, 2016. MMWR Morb Mortal Whly Rep 67:53-59.

Jayaraman S, Al Shoyaib A, Kocot J, Villalba H, Alamri FF, Rashid M, Wangler NJ, Chowdhury EA, German N, Arumugam TV, et al. (2020) Peptidase neurolysin functions to preserve the brain after ischemic stroke in male mice. $J$ Neurochem 153:120-137.

Jha $\mathrm{P}$ (2009) Avoidable global cancer deaths and total deaths from smoking. Nat Rev Cancer 9:655-664.

Jia H (2016) Pulmonary angiotensin-converting enzyme 2 (ACE2) and inflammatory lung disease. Shock 46:239-248.

Jones AR, Overly CC, and Sunkin SM (2009) The Allen brain atlas: 5 years and beyond. Nat Rev Neurosci 10:821-828.

Kaisar MA, Villalba H, Prasad S, Liles T, Sifat AE, Sajja RK, Abbruscato TJ, and Cucullo L (2017) Offsetting the impact of smoking and e-cigarette vaping on the cerebrovascular system and stroke injury: is metformin a viable countermeasure? Redox Biol 13:353-362.

Kaparianos A and Argyropoulou E (2011) Local renin-angiotensin II systems, angiotensin-converting enzyme and its homologue ACE2: their potential role in the pathogenesis of chronic obstructive pulmonary diseases, pulmonary hypertension and acute respiratory distress syndrome. Curr Med Chem 18:3506-3515.

Kaur G, Lungarella G, and Rahman I (2020) SARS-CoV-2 COVID-19 susceptibility and lung inflammatory storm by smoking and vaping. J Inflamm (Lond) 17:21.

Kehoe PG, Miners S, and Love S (2009) Angiotensins in Alzheimer's disease - friend or foe? Trends Neurosci 32:619-628.

Kuba K, Imai Y, Ohto-Nakanishi T, and Penninger JM (2010) Trilogy of ACE2: a peptidase in the renin-angiotensin system, a SARS receptor, and a partner for amino acid transporters. Pharmacol Ther 128:119-128.

Kuba K, Imai Y, Rao S, Gao H, Guo F, Guan B, Huan Y, Yang P, Zhang Y, Deng W, et al. (2005) A crucial role of angiotensin converting enzyme 2 (ACE2) in SARS coronavirus-induced lung injury. Nat Med 11:875-879.

Kumar PA, Hu Y, Yamamoto Y, Hoe NB, Wei TS, Mu D, Sun Y, Joo LS, Dagher R, Zielonka EM, et al. (2011) Distal airway stem cells yield alveoli in vitro and during lung regeneration following H1N1 influenza infection. Cell 147:525-538.

Labandeira-García JL, Garrido-Gil P, Rodriguez-Pallares J, Valenzuela R, Borrajo A and Rodríguez-Perez AI (2014) Brain renin-angiotensin system and dopaminergic cell vulnerability. Front Neuroanat 8:67.

Lawrence H, Hunter A, Murray R, Lim WS, and McKeever T (2019) Cigarette smoking and the occurrence of influenza - systematic review. J Infect 79:401-406.

Leung JM, Yang CX, Tam A, Shaipanich T, Hackett TL, Singhera GK, Dorscheid DR, and Sin DD (2020) ACE-2 expression in the small airway epithelia of smokers and COPD patients: implications for COVID-19. Eur Respir J 55:2000688.

Li F, Li W, Farzan M, and Harrison SC (2005) Structure of SARS coronavirus spike receptor-binding domain complexed with receptor. Science 309:1864-1868.

Li G, He X, Zhang L, Ran Q, Wang J, Xiong A, Wu D, Chen F, Sun J, and Chang C (2020a) Assessing ACE2 expression patterns in lung tissues in the pathogenesis of COVID-19. J Autoimmun 112:102463.

Li Q, Guan X, Wu P, Wang X, Zhou L, Tong Y, Ren R, Leung KSM, Lau EHY, Wong JY, et al. (2020b) Early transmission dynamics in Wuhan, China, of novel coronavirus-infected pneumonia. N Engl J Med 382:1199-1207.

Li W, Sui J, Huang IC, Kuhn JH, Radoshitzky SR, Marasco WA, Choe H, and Farzan M (2007) The S proteins of human coronavirus NL63 and severe acute respiratory syndrome coronavirus bind overlapping regions of ACE2. Virology 367:367-374.

Li Y, Li M, Wang M, Zhou Y, Chang J, Xian Y, Wang D, Mao L, Jin H, and Hu B (2020c) Acute cerebrovascular disease following COVID-19: a single center, retrospective, observational study. Stroke Vasc Neurol 5:279-284.

Li YC, Bai WZ, and Hashikawa T (2020d) The neuroinvasive potential of SARS-CoV2 may play a role in the respiratory failure of COVID-19 patients. J Med Virol 92: $552-555$.

Lind RW, Swanson LW, and Ganten D (1985) Organization of angiotensin II immunoreactive cells and fibers in the rat central nervous system. An immunohistochemical study. Neuroendocrinology 40:2-24.
Lockett AD, Van Demark M, Gu Y, Schweitzer KS, Sigua N, Kamocki K, Fijalkowska I, Garrison J, Fisher AJ, Serban K, et al. (2012) Effect of cigarette smoke exposure and structural modifications on the $\alpha-1$ Antitrypsin interaction with caspases. $M o l$ Med 18:445-454.

Lu H, Rateri DL, Cassis LA, and Daugherty A (2008) The role of the renin angiotensin system in aortic aneurysmal diseases. Curr Hypertens Rep 10:99-106.

Lukassen S, Chua RL, Trefzer T, Kahn NC, Schneider MA, Muley T, Winter H, Meister M, Veith C, Boots AW, et al. (2020) SARS-CoV-2 receptor ACE2 and TMPRSS2 are primarily expressed in bronchial transient secretory cells. EMBO J 39:e105114.

Luo X, Zhou W, Yan X, Guo T, Wang B, Xia H, Ye L, Xiong J, Jiang Z, Liu Y, et al. (2020) Prognostic value of C-reactive protein in patients with COVID-19. Clin Infect Dis DOI: 10.1093/cid/ciaa641 [published ahead of print]

Mabley J, Gordon S, and Pacher P (2011) Nicotine exerts an anti-inflammatory effect in a murine model of acute lung injury. Inflammation 34:231-237.

Mao L, Jin H, Wang M, Hu Y, Chen S, He Q, Chang J, Hong C, Zhou Y, Wang D, et al. (2020a) Neurologic manifestations of hospitalized patients with coronavirus disease 2019 in Wuhan, China. JAMA Neurol 77:683-690.

Mao R, Liang J, Shen J, Ghosh S, Zhu L-R, Yang H, Wu K-C, and Chen M-H; Chinese Society of IBD, Chinese Elite IBD Union; Chinese IBD Quality Care Evaluation Center Committee (2020b) Implications of COVID-19 for patients with pre-existing digestive diseases. Lancet Gastroenterol Hepatol 5:425-427.

Mason RJ (2020) Pathogenesis of COVID-19 from a cell biology perspective. Eur Respir J 55: 2000607.

Matsuo R, Ago T, Kiyuna F, Sato N, Nakamura K, Kuroda J, Wakisaka Y, and Kitazono T; Fukuoka Stroke Registry Investigators (2020) Smoking status and functional outcomes after acute ischemic stroke. Stroke 51:846-852.

McCray PB Jr, Pewe L, Wohlford-Lenane C, Hickey M, Manzel L, Shi L, Netland J, Jia HP, Halabi C, Sigmund CD, et al. (2007) Lethal infection of K18-hACE2 mice infected with severe acute respiratory syndrome coronavirus. J Virol 81:813-821.

Moretto N, Volpi G, Pastore F, and Facchinetti F (2012) Acrolein effects in pulmonary cells: relevance to chronic obstructive pulmonary disease. Ann N Y Acad Sci $\mathbf{1 2 5 9}$ $39-46$

Mossel EC, Wang J, Jeffers S, Edeen KE, Wang S, Cosgrove GP, Funk CJ, Manzer R, Miura TA, Pearson LD, et al. (2008) SARS-CoV replicates in primary human alveolar type II cell cultures but not in type I-like cells. Virology 372:127-135.

Murthy VH (2017) E-cigarette use among youth and young adults: a major public health concern. JAMA Pediatr 171:209-210.

National Center for Chronic Disease Prevention and Health Promotion (US) Office on Smoking and Health (2014) The Health Consequences of Smoking-50 Years of Progress: A Report of the Surgeon General, Centers for Diesease Control and Prevention, Atlanta, GA

Netland J, Meyerholz DK, Moore S, Cassell M, and Perlman S (2008) Severe acute respiratory syndrome coronavirus infection causes neuronal death in the absence of encephalitis in mice transgenic for human ACE2. J Virol 82:7264-7275.

Nordman JC, Muldoon P, Clark S, Damaj MI, and Kabbani N (2014) The $\alpha 4$ nicotinic receptor promotes CD4+ T-cell proliferation and a helper T-cell immune response. Mol Pharmacol 85:50-61.

Oakes JM, Fuchs RM, Gardner JD, Lazartigues E, and Yue X (2018) Nicotine and the renin-angiotensin system. Am $J$ Physiol Regul Integr Comp Physiol $\mathbf{3 1 5}$ R895-R906.

Olds JL and Kabbani N (2020) Is nicotine exposure linked to cardiopulmonary vulnerability to COVID-19 in the general population? FEBS $J$ DOI: 10.1111 / febs.15303 [published ahead of print]

Oxley TJ, Mocco J, Majidi S, Kellner CP, Shoirah H, Singh IP, De Leacy RA, Shigematsu T, Ladner TR, Yaeger KA, et al. (2020) Large-vessel stroke as a presenting feature of covid-19 in the young. N Engl J Med 382:e60.

Park J-E, Jung S, Kim A, and Park JE (2018) MERS transmission and risk factors: a systematic review. BMC Public Health 18:574.

Patanavanich R and Glantz SA (2020) Smoking is associated with COVID-19 progression: a meta-analysis. Nicotine Tob Res 22:1653-1656

Paulson JR, Roder KE, McAfee G, Allen DD, Van der Schyf CJ, and Abbruscato TJ (2006) Tobacco smoke chemicals attenuate brain-to-blood potassium transport mediated by the $\mathrm{Na}, \mathrm{K}, 2 \mathrm{Cl}$-cotransporter during hypoxia-reoxygenation. J Pharmacol Exp Ther 316:248-254.

Paulson JR, Yang T, Selvaraj PK, Mdzinarishvili A, Van der Schyf CJ, Klein J, Bickel U, and Abbruscato TJ (2010) Nicotine exacerbates brain edema during in vitro and in vivo focal ischemic conditions. J Pharmacol Exp Ther 332:371-379.

Perlman S and Netland J (2009) Coronaviruses post-SARS: update on replication and pathogenesis. Nat Rev Microbiol 7:439-450.

Podowski M, Calvi C, Metzger S, Misono K, Poonyagariyagorn H, Lopez-Mercado A $\mathrm{Ku}$ T, Lauer T, McGrath-Morrow S, Berger A, et al. (2012) Angiotensin receptor blockade attenuates cigarette smoke-induced lung injury and rescues lung architecture in mice. J Clin Invest 122:229-240.

Poyiadji N, Shahin G, Noujaim D, Stone M, Patel S, and Griffith B (2020) COVID-19associated acute hemorrhagic necrotizing encephalopathy: imaging features. $R a$ diology 296:E119-E120.

Qian G, Yang N, Ma AHY, Wang L, Li G, Chen X, and Chen X (2020) COVID-19 transmission within a family cluster by presymptomatic carriers in China. Clin Infect Dis 71:861-862.

Qian Z, Travanty EA, Oko L, Edeen K, Berglund A, Wang J, Ito Y, Holmes KV, and Mason RJ (2013) Innate immune response of human alveolar type II cells infected with severe acute respiratory syndrome-coronavirus. Am J Respir Cell Mol Biol 48:742-748.

Rashid M, Wangler NJ, Yang L, Shah K, Arumugam TV, Abbruscato TJ, and Karamyan VT (2014) Functional up-regulation of endopeptidase neurolysin during post-acute and early recovery phases of experimental stroke in mouse brain. $J$ Neurochem 129:179-189.

Razani-Boroujerdi S, Singh SP, Knall C, Hahn FF, Peña-Philippides JC, Kalra R, Langley RJ, and Sopori ML (2004) Chronic nicotine inhibits inflammation and promotes influenza infection. Cell Immunol 230:1-9. 
Reddy RK, Charles WN, Sklavounos A, Dutt A, Seed PT, and Khajuria A (2020) The effect of smoking on COVID-19 severity: a systematic review and meta-analysis. $J$ Med Virol DOI: 10.1002/jmv.26389 [published ahead of print].

Riou J and Althaus CL (2020) Pattern of early human-to-human transmission of Wuhan 2019 novel coronavirus (2019-nCoV), December 2019 to January 2020 Euro Surveill 25:2000058.

Rodrigues Prestes TR, Rocha NP, Miranda AS, Teixeira AL, and Simoes-E-Silva AC (2017) The anti-inflammatory potential of ACE2/angiotensin-(1-7)/Mas receptor axis: evidence from basic and clinical research. Curr Drug Targets 18:1301-1313.

Rojewski AM, Baldassarri S, Cooperman NA, Gritz ER, Leone FT, Piper ME, Toll BA, and Warren GW; Comorbidities Workgroup of the Society for Research on Nicotine and Tobacco (SRNT) Treatment Network (2016) Exploring issues of comorbid conditions in people who smoke. Nicotine Tob Res 18:1684-1696.

Sakima A, Averill DB, Gallagher PE, Kasper SO, Tommasi EN, Ferrario CM, and Diz DI (2005) Impaired heart rate baroreflex in older rats: role of endogenous angiotensin-(1-7) at the nucleus tractus solitarii. Hypertension 46:333-340.

Schelling P, Hutchinson JS, Ganten U, Sponer G, and Ganten D (1976) Impermeability of the blood-cerebrospinal fluid barrier for angiotensin II in rats. Clin Sci Mol Med Suppl 3:399s-402s.

Sifat AE, Vaidya B, Kaisar MA, Cucullo L, and Abbruscato TJ (2018) Nicotine and electronic cigarette (E-Cig) exposure decreases brain glucose utilization in ischemic stroke. J Neurochem 147:204-221.

Smith JC, Sausville EL, Girish V, Yuan ML, Vasudevan A, John KM, and Sheltzer JM (2020) Cigarette smoke exposure and inflammatory signaling increase the expression of the SARS-CoV-2 receptor ACE2 in the respiratory tract. Dev Cell 53:514-529.e3.

Steardo L, Steardo L Jr, Zorec R, and Verkhratsky A (2020) Neuroinfection may contribute to pathophysiology and clinical manifestations of COVID-19. Acta Physiol (Oxf) 229:e13473.

Sungnak W, Huang N, Bécavin C, Berg M, Queen R, Litvinukova M, Talavera-López C, Maatz H, Reichart D, Sampaziotis F, et al.; HCA Lung Biological Network (2020) SARS-CoV-2 entry factors are highly expressed in nasal epithelial cells together with innate immune genes. Nat Med 26:681-687.

Tajlil A, Ghaffari S, Pourafkari L, Mashayekhi S, and Roshanravan N (2020) Nicotine and smoking in the COVID-19 era. J Cardiovasc Thorac Res 12:136-139.

Thomas MC, Pickering RJ, Tsorotes D, Koitka A, Sheehy K, Bernardi S, Toffoli B, Nguyen-Huu TP, Head GA, Fu Y, et al. (2010) Genetic Ace2 deficiency accentuates vascular inflammation and atherosclerosis in the ApoE knockout mouse. Circ Res 107:888-897.

Tipnis SR, Hooper NM, Hyde R, Karran E, Christie G, and Turner AJ (2000) A human homolog of angiotensin-converting enzyme. Cloning and functional expression as a captopril-insensitive carboxypeptidase. J Biol Chem 275:33238-33243.

Tolu S, Eddine R, Marti F, David V, Graupner M, Pons S, Baudonnat M, Husson M, Besson M, Reperant C, et al. (2013) Co-activation of VTA DA and GABA neurons mediates nicotine reinforcement. Mol Psychiatry 18:382-393.

Ulloa L (2005) The vagus nerve and the nicotinic anti-inflammatory pathway. Nat Rev Drug Discov 4:673-684.

Umapathi T, Kor AC, Venketasubramanian N, Lim CC, Pang BC, Yeo TT, Lee CC, Lim PL, Ponnudurai K, Chuah KL, et al. (2004) Large artery ischaemic stroke in severe acute respiratory syndrome (SARS). J Neurol 251:1227-1231.

Vaduganathan M, Vardeny O, Michel T, McMurray JJV, Pfeffer MA, and Solomon SD (2020) Renin-angiotensin-aldosterone system inhibitors in patients with covid19. N Engl J Med 382:1653-1659.

Vardavas CI and Nikitara K (2020) COVID-19 and smoking: a systematic review of the evidence. Tob Induc Dis 18:20.

Wagoner KG, Cornacchione J, Wiseman KD, Teal R, Moracco KE, and Sutfin EL (2016) E-cigarettes, hookah pens and vapes: adolescent and young adult perceptions of electronic nicotine delivery systems. Nicotine Tob Res 18:2006-2012.

Wang D, Hu B, Hu C, Zhu F, Liu X, Zhang J, Wang B, Xiang H, Cheng Z, Xiong Y, et al. (2020a) Clinical characteristics of 138 hospitalized patients with 2019 novel coronavirus-infected pneumonia in Wuhan, China. JAMA 323:1061-1069.
Wang R, Pan M, Zhang X, Han M, Fan X, Zhao F, Miao M, Xu J, Guan M, Deng X, et al. (2020b) Epidemiological and clinical features of 125 hospitalized patients with COVID-19 in fuyang, Anhui, China. Int J Infect Dis 95:421-428.

Weinheimer VK, Becher A, Tönnies M, Holland G, Knepper J, Bauer TT, Schneider P, Neudecker J, Rückert JC, Szymanski K, et al. (2012) Influenza A viruses target type II pneumocytes in the human lung. J Infect Dis 206:1685-1694.

Wu Z and McGoogan JM (2020) Characteristics of and important lessons from the coronavirus disease 2019 (COVID-19) outbreak in China: summary of a report of 72314 cases from the Chinese center for disease control and prevention. JAMA 323:1239-1242.

Xia $\mathrm{H}$ and Lazartigues E (2008) Angiotensin-converting enzyme 2 in the brain: properties and future directions. $J$ Neurochem 107:1482-1494.

Xia H, Suda S, Bindom S, Feng Y, Gurley SB, Seth D, Navar LG, and Lazartigues E (2011) ACE2-mediated reduction of oxidative stress in the central nervous system is associated with improvement of autonomic function. PLoS One 6:e22682.

Xiao D, Xu Z, Huang X, Longo LD, Yang S, and Zhang L (2008) Prenatal genderrelated nicotine exposure increases blood pressure response to angiotensin II in adult offspring. Hypertension 51:1239-1247.

Xu J, Zhong S, Liu J, Li L, Li Y, Wu X, Li Z, Deng P, Zhang J, Zhong N, et al. (2005) Detection of severe acute respiratory syndrome coronavirus in the brain: potential role of the chemokine mig in pathogenesis. Clin Infect Dis 41:1089-1096.

$\mathrm{Xu}$ P, Sriramula S, and Lazartigues E (2011) ACE2/ANG-(1-7)/Mas pathway in the brain: the axis of good. Am J Physiol Regul Integr Comp Physiol 300:R804-R817.

Xu Z, Shi L, Wang Y, Zhang J, Huang L, Zhang C, Liu S, Zhao P, Liu H, Zhu L, et al. (2020) Pathological findings of COVID-19 associated with acute respiratory distress syndrome. Lancet Respir Med 8:420-422.

Yilin Z, Yandong N, and Faguang J (2015) Role of angiotensin-converting enzyme (ACE) and ACE2 in a rat model of smoke inhalation induced acute respiratory distress syndrome. Burns 41:1468-1477.

Yu F, Li Y, Yang J, Qian J, Li X, and Liu C (2017) Prenatal nicotine exposure results in the inhibition of baroreflex sensitivity induced by intravenous injection angiotensin II in the adult male offspring rats. Cardiovasc Toxicol 17:200-207.

Zhang H, Penninger JM, Li Y, Zhong N, and Slutsky AS (2020) Angiotensinconverting enzyme 2 (ACE2) as a SARS-CoV-2 receptor: molecular mechanisms and potential therapeutic target. Intensive Care Med 46:586-590.

Zhang Q, Ding Y, Hou J, He L, Huang Z, Wang H, Cai J, Zhang J, Zhang W, and Geng $\mathrm{J}$ (2003) [Detection of severe acute respiratory syndrome (SARS)-associated coronavirus RNA in autopsy tissues with in situ hybridization]. Di 1 jun yi da xue xue bao 23:1125-1127.

Zhao H, Shen D, Zhou H, Liu J, and Chen S (2020a) Guillain-Barré syndrome associated with SARS-CoV-2 infection: causality or coincidence? Lancet Neurol 19: 383-384.

Zhao Y, Zhao Z, Wang Y, Zhou Y, Ma Y, and Zuo W (2020b) Single-cell RNA expression profiling of ACE2, the receptor of SARS-CoV-2. Am J Respir Crit Care Med 202:756-759.

Zheng YY, Ma YT, Zhang JY, and Xie X (2020) COVID-19 and the cardiovascular system. Nat Rev Cardiol 17:259-260.

Zhou F, Yu T, Du R, Fan G, Liu Y, Liu Z, Xiang J, Wang Y, Song B, Gu X, et al. (2020a) Clinical course and risk factors for mortality of adult inpatients with COVID-19 in Wuhan, China: a retrospective cohort study. Lancet 395:1054-1062.

Zhou P, Yang XL, Wang XG, Hu B, Zhang L, Zhang W, Si HR, Zhu Y, Li B, Huang CL, et al. (2020b) A pneumonia outbreak associated with a new coronavirus of probable bat origin. Nature 579:270-273.

Address correspondence to: Thomas J. Abbruscato, Department of Pharmaceutical Sciences, Texas Tech University Health Sciences Center, 1300 S Coulter St, Amarillo, TX-79106. E-mail: Thomas.abbruscato@ ttuhsc.edu 